\title{
Front Matter: Volume 11817
}

, "Front Matter: Volume 11817," Proc. SPIE 11817, Applied Optical Metrology IV, 1181701 (30 August 2021); doi: 10.1117/12.2606242

SPIE Event: SPIE Optical Engineering + Applications, 2021, San Diego, California, SPIE. United States 


\section{PROCEEDINGS OF SPIE}

\section{Applied Optical Metrology IV}

Erik Novak

James D. Trolinger

Christopher C. Wilcox

Editors

1-5 August 2021

San Diego, California, United States

Sponsored and Published by

SPIE 
The papers in this volume were part of the technical conference cited on the cover and title page. Papers were selected and subject to review by the editors and conference program committee. Some conference presentations may not be available for publication. Additional papers and presentation recordings may be available online in the SPIE Digital Library at SPIEDigitalLibrary.org.

The papers reflect the work and thoughts of the authors and are published herein as submitted. The publisher is not responsible for the validity of the information or for any outcomes resulting from reliance thereon.

Please use the following format to cite material from these proceedings:

Author(s), "Title of Paper," in Applied Optical Metrology IV, edited by Erik Novak, James D. Trolinger, Christopher C. Wilcox, Proc. of SPIE 11817, Seven-digit Article CID Number (DD/MM/YYYY); (DOI URL).

ISSN: 0277-786X

ISSN: 1996-756X (electronic)

ISBN: 9781510644724

ISBN: 9781510644731 (electronic)

Published by

SPIE

P.O. Box 10, Bellingham, Washington 98227-0010 USA

Telephone +1 3606763290 (Pacific Time)

SPIE.org

Copyright @ 2021 Society of Photo-Optical Instrumentation Engineers (SPIE).

Copying of material in this book for internal or personal use, or for the internal or personal use of specific clients, beyond the fair use provisions granted by the U.S. Copyright Law is authorized by SPIE subject to payment of fees. To obtain permission to use and share articles in this volume, visit Copyright Clearance Center at copyright.com. Other copying for republication, resale, advertising or promotion, or any form of systematic or multiple reproduction of any material in this book is prohibited except with permission in writing from the publisher.

Printed in the United States of America by Curran Associates, Inc., under license from SPIE.

Publication of record for individual papers is online in the SPIE Digital Library.

\section{SPIE. DIGITAL}

Paper Numbering: A unique citation identifier (CID) number is assigned to each article in the Proceedings of SPIE at the time of publication. Utilization of CIDs allows articles to be fully citable as soon as they are published online, and connects the same identifier to all online and print versions of the publication. SPIE uses a seven-digit CID article numbering system structured as follows:

- The first five digits correspond to the SPIE volume number.

- The last two digits indicate publication order within the volume using a Base 36 numbering system employing both numerals and letters. These two-number sets start with 00, 01, 02, 03, 04, 05, 06, 07, 08, 09, OA, OB ... 0Z, followed by 10-1Z, 20-2Z, etc. The CID Number appears on each page of the manuscript. 


\section{Contents}

\section{SURFACE METROLOGY}

1181702 Measurements with a capacitance gauge for sub-nanometer thermal expansion characterization of optical components (Invited Paper) [1 1817-1]

1181704 Binary pseudo-random array test standard optimized for characterization of interferometric microscopes [11817-6]

1181705 Measurement systems in the UV A/B/C range [1 1817-7]

1181707 A new approach in optical metrology with multi-angle information through self-interferometric ellipsometry [1 1817-4]

1181709 A displacement probe using backscattering for profiling the ground surface form [11817-8]

\section{HOLOGRAPHY AND INTERFEROMETRY}

11817 OA Noise suppression methods in picometer heterodyne displacement interferometer [1 1817-13]

11817 OB A versatile digital holography software for three-dimensional investigations [1 1817-9]

11817 OD Fabry-Perot interferometric sensor to measuring vibrations in mechanical structures based on the Doppler effect [1 1817-12]

\section{INDUSTRIAL MEASUREMENT}

11817 OE Physics-informed machine-learning for modeling aero-optics (Keynote Paper) [11817-14]

11817 OG Micro-fabrication of Si-based optomechanical inertial sensors for cryogenic temperatures [11817-18]

$11817 \mathrm{OH} \quad$ Determining material parameters with resonant acoustic spectroscopy [11817-16]

118170 Ol Defect detection in additive manufactured products with a new photonics procedure: a case study [11817-17]

$11817 \mathrm{OL} \quad$ Progress and characterization of battery-operated microplasmas by a portable optical emission spectrometer [11817-21] 
11817 OM Fourier optics modelling of coherence scanning interferometers (Invited Paper) [11817-23]

11817 ON The state of the art in swept-wavelength laser Fizeau interferometry (Invited Paper) [1 1817-22]

1181700 Suppression of light-field shift of CPT resonances in optically dense media [11817-24]

11817 OP Statistical analysis of speckle patterns modeled with OpticStudio® [1 1817-26]

$118170 Q \quad$ Simultaneous direct and indirect wavefront sensing using multiplexed programmable grating patterns [11817-27]

11817 OR An improved programmable grating array based wavefront sensor [11817-28]

\section{POSTER SESSION}

11817 OS The two-dimensional Gaussian filter weighting function for the cylindrical surface [1 1817-29] 